\title{
Insights into rates, risks and characteristics of suicide by immigration background in Norway
}

\author{
By Quirino Puzo, Lars Mehlum og Ping Qin
}

\begin{abstract}
SAMMENDRAG
Selv om de fleste innvandrere synes å håndtere utfordringene knyttet til innvandringsprosessen godt, har man stilt spørsmål om sårbare grupper kan ha økt risiko for selvmord. Dette gjelder særlig i land med økende innvandring, slik tilfellet er i Norge. Denne artikkelen oppsummerer forskningsfunn i forhold til selvmord blant ulike innvandrergrupper, basert på tre norske, nylig utførte studier der vi benytter de unike mulighetene ved nasjonale befolkningsregistre. Dataene viste at førstegenerasjonsinnvandrere hadde en relativt lavere risiko for selvmord sammenlignet med etnisk norske, mens risikoen for selvmord blant mennesker som hadde blandet norsk bakgrunn og innvandrerbakgrunn var betydelig høyere. Selvmordsrisiko var forbundet med en rekke sosioøkonomiske ulemper i alle befolkningsgruppene, men hvor sterk sammenhengen var mellom sosioøkonomiske faktorer og selvmord varierte med spesifikk innvandringsbakgrunn, med en generelt svakere sammenheng blant førstegenerasjonsinnvandrere enn innfødte. Det var imidlertid betydelige forskjeller blant innvandrergrupper med hensyn til hvilken selvmordsmetode de benyttet, tid på året da selvmordet skjedde og tid fra man innvandret til Norge og til selvmordet inntraff. Disse funnene understreker viktigheten av å behandle innvandrere som den meget heterogene gruppe de er i forhold til forekomst av selvmord og risikofaktorer. Variasjoner i innvandrergruppen når det gjelder selvmordsatferd, bør tas hensyn til ved planlegging av folkehelsepolitikk og forebyggende tiltak, for bedre å skreddersy disse tiltakene til risikoutsatte innvandrergrupper.
\end{abstract}

Although most immigrants seem to successfully manage the challenges their immigration process entails, suicide mortality of minority groups has become an important public concern, particularly in countries with growing segments of immigrant populations such as Norway. The present article aimed to summarize insights into suicide among various immigrant populations, obtained by three Norwegian studies we recently conducted utilizing the unique possibilities of national population registers. First-generation immigrants had a relatively lower risk of suicide than native Norwegians, whereas the risks for people with mixed Norwegian and immigrant background were significantly higher. Suicide risk was associated with a range of socio-economic disadvantages in all populations, but the strength of the association differed by specific immigration background, with a generally weaker association in first-generation-immigrants than natives. In the meantime, there were notable differences in characteristics of suicide by immigration background with respect to method of suicide, month of the year when suicide occurred, and time to suicide since immigration. All these insights underscore the importance of treating immigrants as a very heterogeneous group, and differences in suicides by specific immigration background should be considered when planning public health policies and prevention measures in order to more effectively tailor these measures to at-risk immigrant populations. 


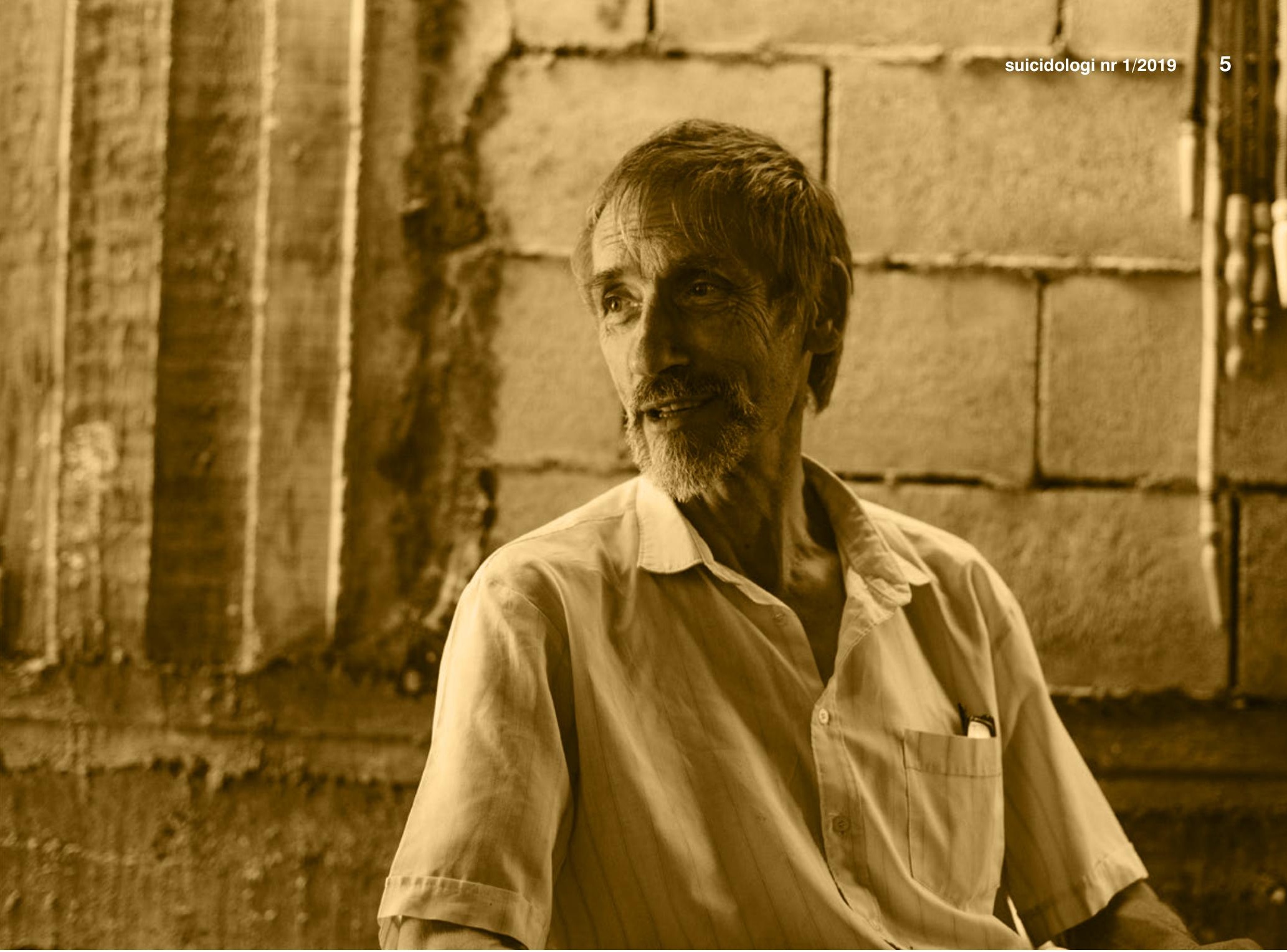

SUICIDE MORTALITY in immigrant populations is an important health issue, particularly in nations with growing segments of immigrants such as Norway. According to Statistics Norway, the proportion of first- and second-generation immigrants in Norway has gradually increased from around $1.5 \%$ of the national population in the early 1970 s to $16.8 \%$ in 2017 , with a total of 883,751 persons (SSB, 2017a). Studies in this field have shown that people with an immigration background may be prone to increased risks of mental disorders and suicidal behaviour due to multiple stresses experienced in the host country (Bhugra, 2004; Bhugra \& Becker, 2005; Henrik Mäkinen \& Wasserman, 2003; Mirsky, Kohn, Dolberg, \& Levav, 2011; Mirsky, Kohn, Levav, Grinshpoon, \& Ponizovsky, 2008). Such mental problems may be influenced by psychosocial distress, as well as by different factors such as culture of origin, positive or negative life events, relative social and economic marginalization from the majority society, and the weakened connections to previous family and social networks (Berkman, Glass, Brissette, \& Seeman, 2000; Kposowa, McElvain, \& Breault, 2008; Mirsky et al., 2011; Ratkowska \& Leo, 2013). Results from a considerable number of studies investigating the relationship between immigration and suicide, and in particular studies comparing suicide rate in immigrants to that of the native population are divergent. Most studies have shown that immigrants tend to retain the suicide rates of their country of origin, even when moving to a new country (Burvill, 1998; Ide, Kolves, Cassaniti, \& De Leo, 2012; E. Kliewer, 1991), while some studies have shown that the suicide rates of immigrant groups tend to match those of the native population in the host country (E. Kliewer, 1991; E. V. Kliewer \& Ward, 1988). There are also studies demonstrating that foreign-born persons (persons born in a country other than the one in which they reside) have a significantly higher rate of suicide death compared with the native population (Leena Maria Johansson et al., 1997; Johansson, Sundquist, Johansson, Qvist, \& Bergman, 1997). However, among these studies only a few have tried to look into suicide risk differences in subpopulations of individuals by various immigration background characteristics. Two Swedish studies have shown that first-generation immigrants (born outside Sweden with both parents born outside Sweden) had a lower suicide risk compared to Swedish-born citizens with both parents born in Sweden, while the risk for individuals 


\section{A better understanding of the interplay between suicide and immigration is of fundamental importance as a basis for planning future public policies for immi- grant minorities living in the country.}

with one parent born in Sweden and one parent born abroad and second-generation immigrants (born in Sweden with both parents born outside Sweden) was found to be higher (Di Thiene, Alexanderson, Tinghög, La Torre, \& Mittendorfer-Rutz, 2015; Hjern \& Allebeck, 2002). In contrast, an Australian study found no significant difference in terms of suicide risk among second-generation immigrants in Australia as compared to the natives (Law, Kõlves, \& De Leo, 2014). The few and inconsistent studies published so far indicate that there is currently an insufficient amount of research into absolute rates and risks of suicide by segments of immigrants, and a lack of knowledge regarding detailed characteristics of suicide by immigration background. A better understanding of the interplay between suicide and immigration is of fundamental importance as a basis for planning future public policies for immigrant minorities living in the country. This article summarizes core findings from three studies we recently conducted (Puzo, Mehlum, \& Qin, 2017, 2018a, 2018b) with data from Norwegian national registers addressing suicide risk among various immigrant populations from an epidemiological perspective. In particular, we highlight important findings about suicide rates and risks for people with various immigration backgrounds as compared with native Norwegians, the impact of a range of socio-economic factors on risk of suicide as well as differential characteristics of suicides by immigration background with respect to method of suicide, seasonality of suicide and time to suicide since immigration.

\section{Materials and Methods}

\section{Data Sources, Study Design and Population}

Data for the published studies were retrieved from three Norwegian national longitudinal registers that were interlinked on an individual level via the encrypted personal identifier of all residents in Norway. The Cause-of-Death Register contains dates and causes of all deaths in Norway since the year 1969. Suicide was coded according to the International Classification of Diseases (ICD), 9th Revision for the years 1992-95 (codes E950-E959) and 1oth Revision for the years 19962012 (codes X6o-X84, Y870). The Central Population Register, computerized since the year 1964, includes personal information on all subjects who were alive and residing in Norway since 196o. It contains demographic data such as country of birth, citizenship, date of immigration or emigration, alongside with sex, date of birth and links to parents. The Statistics Norway's
Events Database (FD-Trygd) contains data on personal socio-economic status such as marital status, education attainment, annual income and place of residence. Running data on all residents have become available in this database since its establishment in 1992.

Study cases were all completed suicides from the Cause-of-Death Register from the year 1969 through 2012 and were restricted to subjects residing in Norway at the time of their suicide, yielding a total of 23,073 suicide cases. Population controls were drawn from a $25 \%$ representative sample of the national population in the Central Population Register through a nested case control design (Clayton, Hills, \& Pickles, 1993). Each suicide case was matched on sex and date of birth with up to 20 individuals who were alive at the date of case suicide, yielding a total of 373,178 comparison controls.

\section{Variables}

Data on immigration background for the population under study was obtained from the Central Population Register, and categorized into the following five groups: native Norwegians (Norwegian-born persons to two Norwegian-born parents), first-generation immigrants (foreign-born persons to two foreign-born parents), second-generation immigrants (Norwegian-born persons to two foreign-born parents), Norwegian-born persons with one foreign-born parent, and foreign-born individuals with at least one Norwegian-born parent (including intercountry adoptees, for which our data sources did not allow us to distinguish). The categorization was made upon available information of legal parents since the establishment of Central Population Register in 1964 (Nystadnes, 2010).

Socio-economic factors included in the studies were marital status, education attainment, annual income, and place of residence. This information was drawn from the Statistics Norway's Events database for the period 1992-2012. Marital status was categorized as "married", "single" (never married), "separated, divorced or widowed" and "unknown marital status". Education attainment, either achieved in Norway or abroad, was classified into four independent categories based on the Norwegian Standard Classification of education NUS2000 (SSB, 2003), including "compulsory education" (primary education and lower secondary education), "intermediate education" (upper secondary or post-secondary non-tertiary education), "tertiary education" (bachelor, master or doctoral degrees), and "no education or unknown education". Annual gross income includes wages, pensions, entrepreneurial income and property income (SSB, 2017d), and was divided into the following categories: " $200,000 \mathrm{NOK}$ or less", "200,001-300,000 NOK", "300,001-400,000 NOK", "more than 400,000 NOK", and "unknown annual income". Information concerning income was only available from 1993 and was extracted for the year prior to the year of suicide or matching; therefore, 


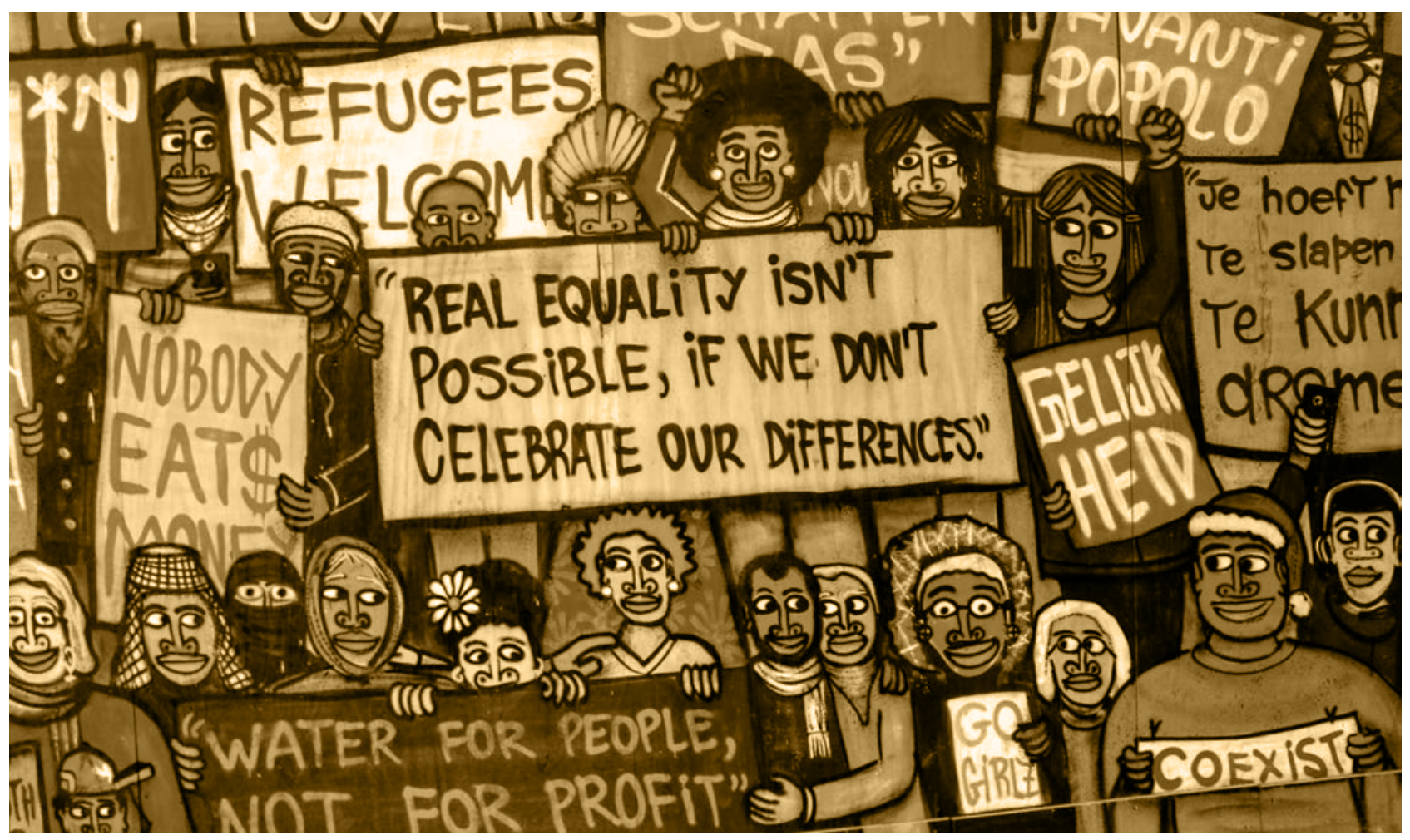

Humanity wall i Ghent, Belgia.

people with a suicide or matching date before 1994 make up the majority of the missing category. Place of residence was classified as whether or not residing in the capital area of Norway (Oslo and Akershus counties) at the time of suicide or matching for the controls.

Data on method of suicide were retrieved from the Cause-of-Death Register for the period 1992-2012 and classified into seven categories by diagnostic codes in ICD-10: "Poisoning" (E950-E952 or X6o-X69), "Hanging" (E953 or X70), "Drowning" (E954 or X71), "Firearms and explosive material" (E955 or X72-X75), "Cutting or piercing instruments" (E956 or X78), "Iumping from a high place" (E957 or X80) and "Other or unknown method" (E958-E959 or X76-77, X79, X81-84, Y870).

The variable month of suicide refers to the month of the year when the suicide occurred.

The variable time since immigration refers to the time span between the date of immigration to Norway (i.e., registered as resident in the population registration system) and the date of suicide death, and it was classified with yearly increments (up to 1 year, 1-up to 2 years, 2 -up to 3 years, etc.). This variable applies only to first-generation immigrants.

\section{Statistical analyses}

All data were analysed using the R statistical software (version 3.3.3) (RCoreTeam, 2017). Relative risks of suicide according to subjects' immigration background and country group of origin were estimated using conditional logistic regression (Collett, 1991) for the period 1969-2012, only controlling for the effect of sex, date of birth and calendar year through matching, and for the period 1992-2012, further adjusting for socio-economic factors. Conditional logistic regression was also used to estimate the effect of each socio-economic factor on risk of suicide by immigration background for the period 1992-2012. Overall effect differences of a specific factor on suicide risk across various immigrant populations were tested by the log likelihood ratio test. Difference in the degree of associations between socio-economic factors and risk of suicide across specific immigrant groups were tested using the 'linearHypothesis' procedure in R.

Rates of suicide (expressed as number per 100,000 population) for various immigration groups by sex were calculated for the period 1992-2012. T-test for independent 2-groups was used to assess differences in suicide mortality rates among the investigated subpopulations.

Characteristics of suicides by immigration background (observed in the period 1992-2012) with respect to method of suicide, seasonality of suicide and time since immigration were analysed. Fisher's exact test was conducted to assess differences in method of suicide between the immigrant groups. Chi-square goodness of fit test was used to verify whether the observed 
distribution of suicides in the groups was invariant by month of the year. Mann-Whitney test was performed to assess differences in time since immigration among first-generation immigrants by sex and by country group of origin.

$P$ values smaller than $5 \%$ were considered to be statistically significant.

\section{Ethical considerations}

Access to data for the studies whom this paper refers to (Puzo et al., 2017, 2018a, 2018b) was approved by the Regional Ethical Committee for Medical and Health Research (REK South-East) and owners of the relevant individual registers.

\section{Results}

The 23,073 suicides occurred during 1969-2012 in Norway comprised 21,321 (92.4\%) native Norwegians and $1,752(7.6 \%)$ persons with an immigration background. The latter group comprised 940 (4.1\%) first-generation immigrants, 34 ( $0.1 \%$ ) second-generation immigrants, 533 (2.3\%) born in Norway with one foreign-born parent, and 245 (1.1\%) born abroad with at least one Norwegian-born parent.

Rates and relative risks of suicide by immigration background Considering both sexes combined, the suicide mortality rate (per 100,000 population, data period 1992-2012) was 12.22 for native Norwegians, 9.53 for first-generation immigrants, 2.56 for second-generation immigrants, 11.13 for Norwegian-born with one foreign-born parent, and 17.10 for foreign-born with at least one Norwegianborn parent (Table 1). First-generation immigrants had a significantly lower suicide rate than native Norwegians (9.53 vs $12.22, P<0.01$ ), with a difference that remained statistically significant only among males (12.73 vs $18.03, P<0.01$ ) and not among females (6.29 vs 6.54 , $P=0.56)$. No differences were observed in suicide rates between Norwegian-born with one foreign-born parent and native Norwegians ( 15.70 vs 18.03 in males, $P=0.06 ; 6.21$ vs 6.54 in females, $P=0.67$ ). The suicide rate of foreign-born persons with at least one Norwegian-born parent was significantly higher than that of natives, for both sexes (22.42 vs 18.03 in males, $P<0.01 ; 11.67$ vs 6.54 in females, $P<0.01$ ).

Similar patterns were observed in the analyses of relative suicide risks by immigration background, using the data from suicide cases and their sex-birthdatematched controls (Table 2). Considering the period 1969-2012, first-generation immigrant status was significantly associated with a lower crude risk of suicide (OR: 0.75, 95 \% CI: 0.70-0.81) compared with native Norwegians. In particular, first-generation immigrants from Asia and Africa represented the groups with the lowest risk of suicide compared to natives; while no significant difference was detected between first-generation immigrants from Nordic countries and natives.

Second-generation immigrants also showed a lower associated risk of suicide, though not at a highly significant level. Both Norwegian-born subjects with one foreign-born parent and foreign-born individuals with at least one Norwegian-born parent had a higher risk of suicide (OR: 1.13, $95 \%$ CI: 1.04-1.24 and OR: 1.29, $95 \%$ CI: 1.14-1.48, respectively) in comparison with the native population. Among foreign-born individuals with at least one Norwegian-born parent, those born in Asia and Central and South America showed the highest risk of suicide, compared to native Norwegians. When socio-economic factors were taken into account for the period 1992-2012, the reduced risk of suicide in both first- and second-generation immigrants, in comparison with natives, became even more significant (adjusted OR: 0.56, 95 \% CI: 0.51-0.62 and adjusted OR: 0.68, $95 \%$ CI: $0.47-0.98$, respectively). The overall effect of immigration background on suicide risk differed significantly by sex (sex interaction test: $P<0.01$ ) (Table 2 ).

Table 1. Suicide rate (per 100,000 population) by immigration background, 1992-2012

\begin{tabular}{|l|r|r|r|}
\hline & \multicolumn{3}{|c|}{ Average annual sulicide ratea $(95 \% \mathrm{CI})$} \\
\hline Immigration Background & \multicolumn{1}{|c|}{ Both sexes } & \multicolumn{1}{|c|}{ Females } \\
\hline Native Norwegians & $12.22(11.8-12.6)$ & $18.03(17.3-18.8)$ & $6.54(6.3-6.8)$ \\
\hline First-generation immigrants & $9.53(8.7-10.4)$ & $12.73(11.5-14.0)$ & $6.29(5.5-7.1)$ \\
\hline Second-generation immigrants & $2.56(1.5-3.6)$ & $3.99(1.9-6.1)$ & $1.05(0.2-1.9)$ \\
\hline Norwegian-born with one foreign-born parent & $11.13(9.7-12.6)$ & $15.70(13.6-17.8)$ & $6.21(4.7-7.7)$ \\
\hline Foreign-born with at least one Norwegian-born parent & $17.10(14.6-19.6)$ & $22.42(18.9-25.9)$ & $11.67(8.3-15.0)$
\end{tabular}

a Suicide rates were not age-standardized because the age distribution of all immigrant populations was not available. 


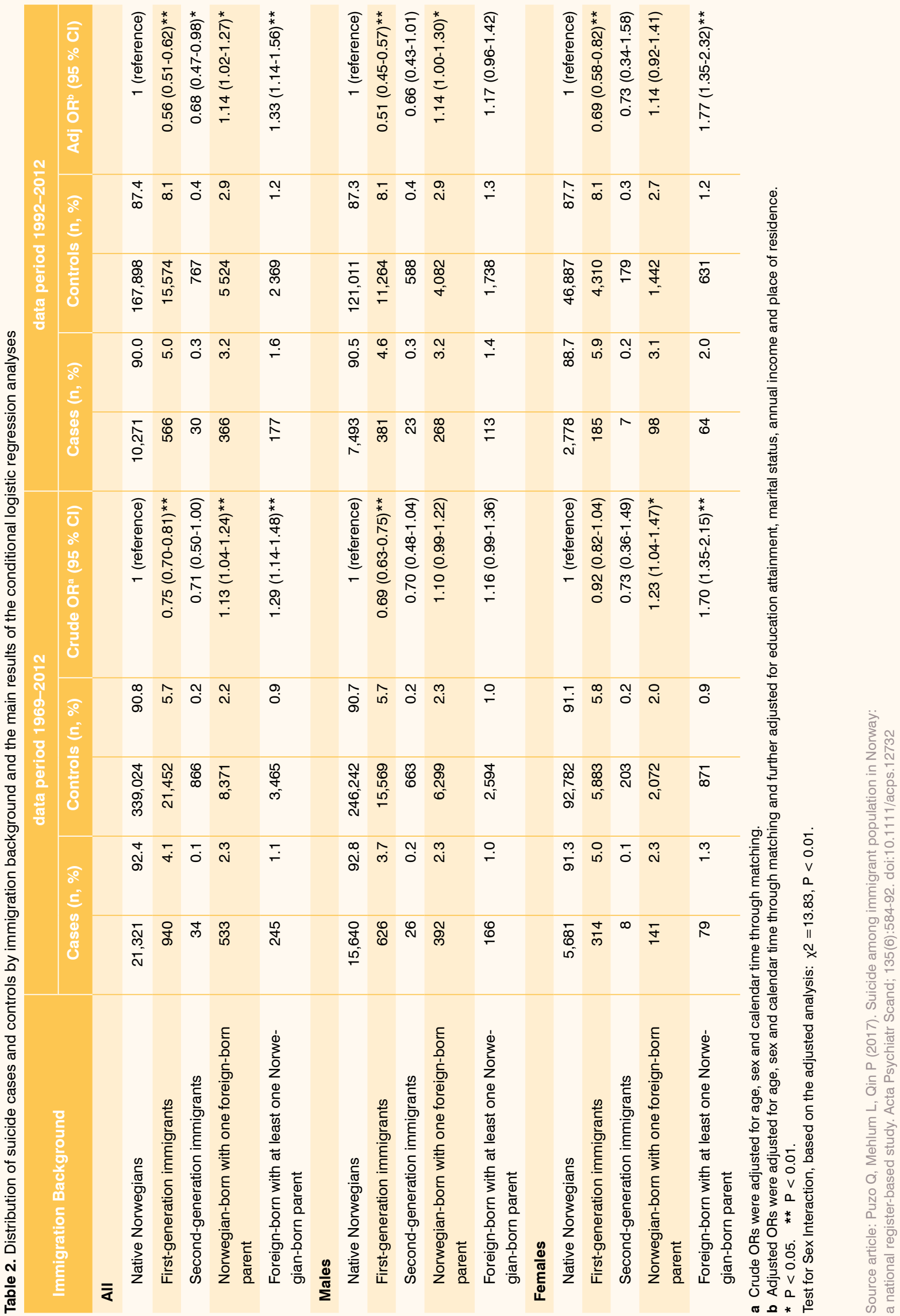




\section{Influence of socio-economic factors on risk of suicide}

As shown in Table 3, being single, or separated, divorced or widowed, compared to being married, was associated with increased risk of suicide both in native Norwegians and in persons with an immigration background. The influence of a single marital status was less strong in first-generation immigrants (adjusted OR: 1.89, 95 \% CI: 1.53-2.33) than in natives $(P<0.01)$. A status of "separated, divorced or widowed" showed a much stronger negative effect in foreign-born subjects with at-least one Norwegian born-parent (adjusted OR: 7.12, 95 \% CI: 3.6o-14.09) compared to native Norwegians ( $P=0.039$ ).

In almost all populations, risk of suicide rose significantly with decreasing levels of education attainment and annual income. The elevated risk associated with low income (200,000 NOK or less) was less prominent for first-generation immigrants (adjusted OR: 1.96, $95 \%$ CI: 1.53-2.33) than for native Norwegians $(P<0.01)$.

Living in the capital area, compared to living in other areas in Norway, was associated with a reduced risk of suicide in first-generation immigrants (adjusted OR: 0.78, 95 \% CI: 0.65-0.93) but an increased risk in native Norwegians (adjusted OR: 1.14, 95 \% CI: 1.08-1.20) (Table 3).

\section{Characteristics of suicides}

In all the investigated populations, hanging was the most frequently used suicide method, accounting for

Table 3. Conditional logistic regression analyses of socio-economic factors on risk of suicide among the natives and persons with various immigration backgrounds

\begin{tabular}{|c|c|c|c|c|c|c|}
\hline $\begin{array}{l}\text { Socio-economic } \\
\text { factors }\end{array}$ & $\begin{array}{l}\text { Native } \\
\text { Norwegians }\end{array}$ & $\begin{array}{l}\text { First- } \\
\text { generation } \\
\text { immigrants }\end{array}$ & $\begin{array}{l}\text { Second- } \\
\text { generation } \\
\text { immigrants }\end{array}$ & $\begin{array}{l}\text { Norwegian- } \\
\text { born with one } \\
\text { foreign-born } \\
\text { parent }\end{array}$ & $\begin{array}{l}\text { Foreign-born } \\
\text { with at least } \\
\text { one Norwegian- } \\
\text { born parent }\end{array}$ & \multirow[t]{2}{*}{$\begin{array}{l}\text { Test of } \\
\text { Interaction } \\
\text { of risk } \\
\text { factor }^{\mathrm{b}}\end{array}$} \\
\hline & \multicolumn{5}{|c|}{ Adj ORa (95\% CI) } & \\
\hline \multicolumn{6}{|l|}{ Marital status } & \multirow{5}{*}{$\begin{array}{c}X^{2}=30.85 \\
P<0.01\end{array}$} \\
\hline Married $^{c}$ & 1 & 1 & 1 & 1 & 1 & \\
\hline Single & $2.82(2.65-2.99)^{\star \star}$ & $1.89(1.53-2.33)^{\star *}$ & $2.77(0.74-10.34)$ & $2.18(1.60-2.96)^{\star \star}$ & $6.01(3.32-10.88)^{\star \star}$ & \\
\hline $\begin{array}{l}\text { Being Separated, } \\
\text { Divorced or Widowed }\end{array}$ & $3.46(3.27-3.66)^{\star \star}$ & $3.08(2.49-3.80)^{\star *}$ & $8.32(1.81-38.30)^{\star *}$ & $3.00(2.06-4.36)^{\star \star}$ & $7.12(3.60-14.09)^{\star *}$ & \\
\hline Unkown marital status & - & - & - & - & - & \\
\hline Education attainment & & & & & & \\
\hline Tertiary education ${ }^{c}$ & 1 & 1 & 1 & 1 & 1 & \\
\hline Intermediate education & $1.17(1.10-1.24)^{\star \star}$ & $1.02(0.78-1.33)$ & $0.48(0.15-1.56)$ & $1.02(0.73-1.41)$ & $1.56(1.00-2.42)^{\star}$ & $\chi^{2}=28.59$ \\
\hline Compulsory education & $1.56(1.46-1.67)^{\star \star}$ & $1.31(1.01-1.70)^{*}$ & $1.24(0.43-3.52)$ & $2.10(1.53-2.90)^{\star \star}$ & $1.89(1.20-2.97)^{\star \star}$ & \\
\hline No education or unknown & $1.58(1.29-1.94)^{\star \star}$ & $2.17(1.69-2.79)^{\star *}$ & $1.14(0.26-5.05)$ & $2.00(1.11-3.62)^{*}$ & $1.56(0.65-3.76)$ & \\
\hline Education & - & - & - & - & - & \\
\hline Annual gross income & & & & & & \\
\hline more than $400,000 \mathrm{kr}^{\mathrm{c}}$ & 1 & 1 & 1 & 1 & 1 & \\
\hline $300,001-400,000 \mathrm{kr}$ & $1.44(1.32-1.58)^{\star \star}$ & $1.00(0.67-1.48)$ & $0.91(0.18-4.59)$ & $1.57(0.88-2.81)$ & $1.66(0.74-3.69)$ & \\
\hline $200,001-300,000 \mathrm{kr}$ & $1.97(1.81-2.15)^{\star *}$ & $1.57(1.11-2.21)^{\star *}$ & $0.98(0.21-4.69)$ & $3.34(2.03-5.47)^{\star \star}$ & $3.56(1.77-7.15)^{\star \star}$ & $\begin{array}{l}X^{2}=29.04 \\
P=002\end{array}$ \\
\hline $\begin{array}{l}200,000 \mathrm{kr} \text { or less unkown } \\
\text { annual income }\end{array}$ & $3.03(2.78-3.30)^{\star *}$ & $1.96(1.44-2.68)^{\star *}$ & $1.13(0.29-4.41)$ & $5.46(3.44-8.67)^{\star \star}$ & $5.01(2.62-9.61)^{\star \star}$ & \\
\hline unkown annual income & - & - & - & - & - & \\
\hline Place of residence & & & & & & $x^{2}=22.54$ \\
\hline Others ${ }^{c}$ & 1 & 1 & 1 & 1 & 1 & ${ }^{n} P<0.01$ \\
\hline Capital aread & $1.14(1.08-1.20)^{\star *}$ & $0.78(0.65-0.93)^{\star \star}$ & $0.56(0.26-1.20)$ & $0.98(0.77-1.24)$ & $0.86(0.61-1.22)$ & \\
\hline
\end{tabular}

a Adj ORs were adjusted for age, sex and calendar time through matching further adjusted for all other variables shown in the table.

b A log likelihood ratio test was performed separately for each socio-economic variable based on adjusted analyses.

c Reference category. d The capital area encompassed the Oslo and Akershus counties. ${ }^{*} \mathrm{P}<0.05$. $\quad{ }^{* \star} \mathrm{P}<0.01$

Source article: Puzo Q, Mehlum L, Qin P (2018). Socio-economic status and risk for suicide by immigration background in Norway: A register-based national study. Journal of Psychiatric Research; 100:99-106. doi:10.1016/j.jpsychires.2018.02.019 
Figure 1. Distribution of suicide cases by specific methods in various age groups of native Norwegians and first-generation immigrants, 1992-2012

\section{MALES}
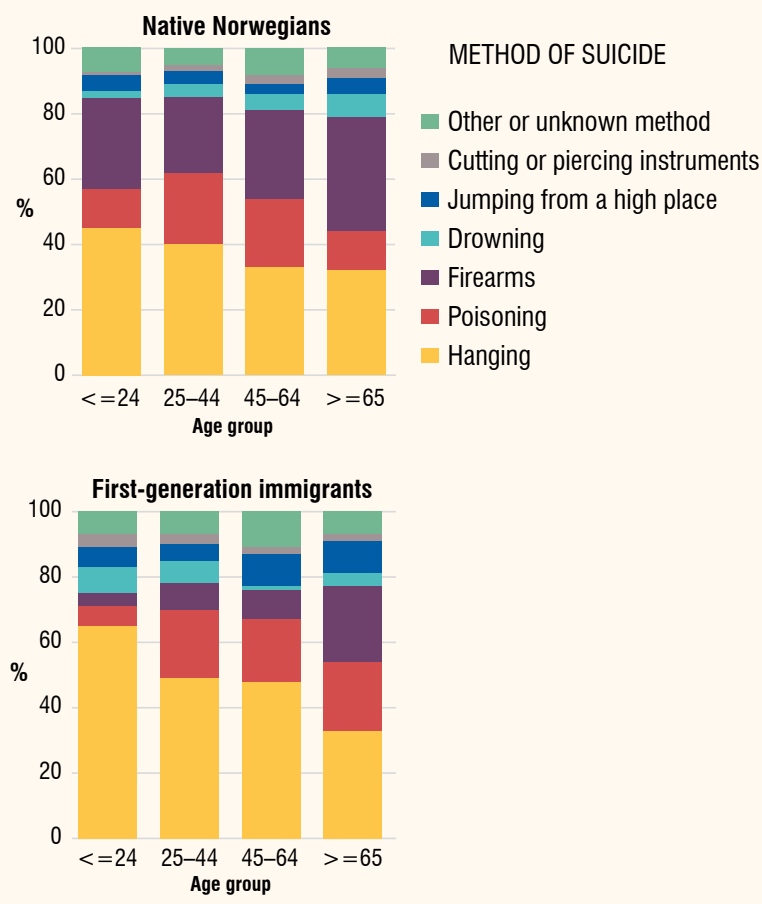

\section{FEMALES}

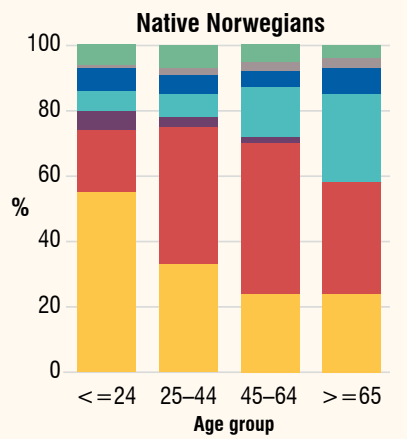

\section{METHOD OF SUICIDE}

- Other or unknown method

- Cutting or piercing instruments

- Jumping from a high place

- Drowning

- Firearms

- Poisoning

Hanging

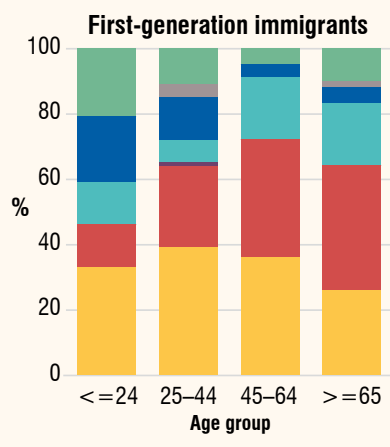

Source article: Puzo Q, Mehlum L, Qin P (2018). Rates and characteristics of suicide by immigration background in Norway. PLoS ONE 13(9):e0205035. doi:10.1371/journal.pone.
$44.0 \%$ of all suicides of first-generation immigrants and $35.4 \%$ of all suicides of natives. The proportion of suicides by firearm was much smaller in first-generation immigrants $(6.7 \%)$ than in native Norwegians $(20.7 \%)$. In particular, male subjects in the age group ' 24 years old or less' who died by firearms represented $4.1 \%$ of suicides in first-generation immigrants and $27.8 \%$ of suicides of native Norwegians (Fig 1). Females aged 24 years or less more frequently died by hanging in both natives and first-generation immigrants, whereas females aged 45 years or more mostly died by poisoning (Fig 1).

Different patterns of suicide occurrence by month of the year were observed when comparing natives and first-generation immigrants, as shown in Fig 2. The distribution of suicides of native Norwegians showed an increase of cases in May ( $9.2 \%$ of all suicides) $(P<0.01)$; suicides of first-generation immigrants demonstrated a tendency of an increased occurrence in May and in November ( $11.7 \%$ and $11.1 \%$ of all cases, respectively) $(P=0.01)$.

Figure 2. Monthly distribution of suicides of the natives and the first-generation immigrants, 1992-2012 (\%)

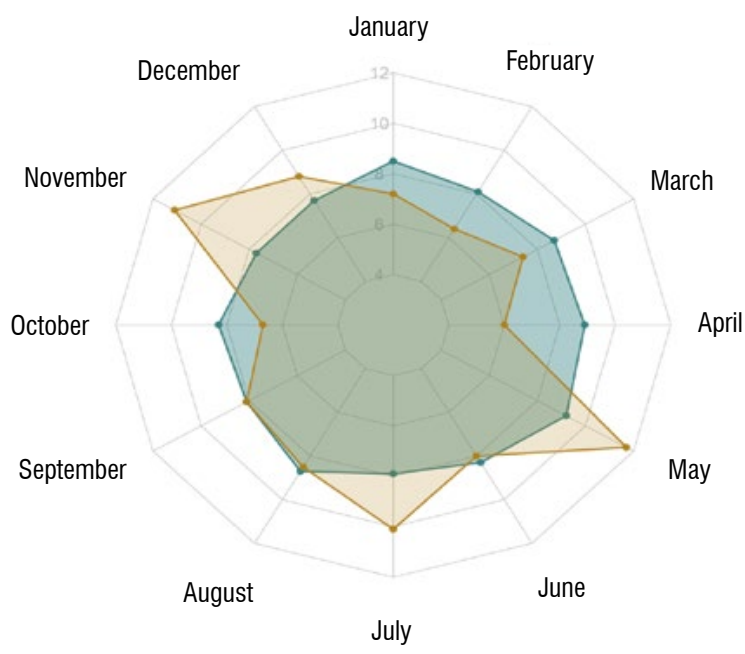

Native Norwegians 0205035 characteristics of suicide by immigration background in Norway. PLoS ONE 13(9):e0205035. doi:10.1371/journal.pone.0205035
Source article: Puzo Q, Mehlum L, Qin P (2018). Rates and 
Figure 3. Cumulative percentage distribution of suicides of first-generation immigrants by sex (a) and country group of origin (b) according to the time since immigration
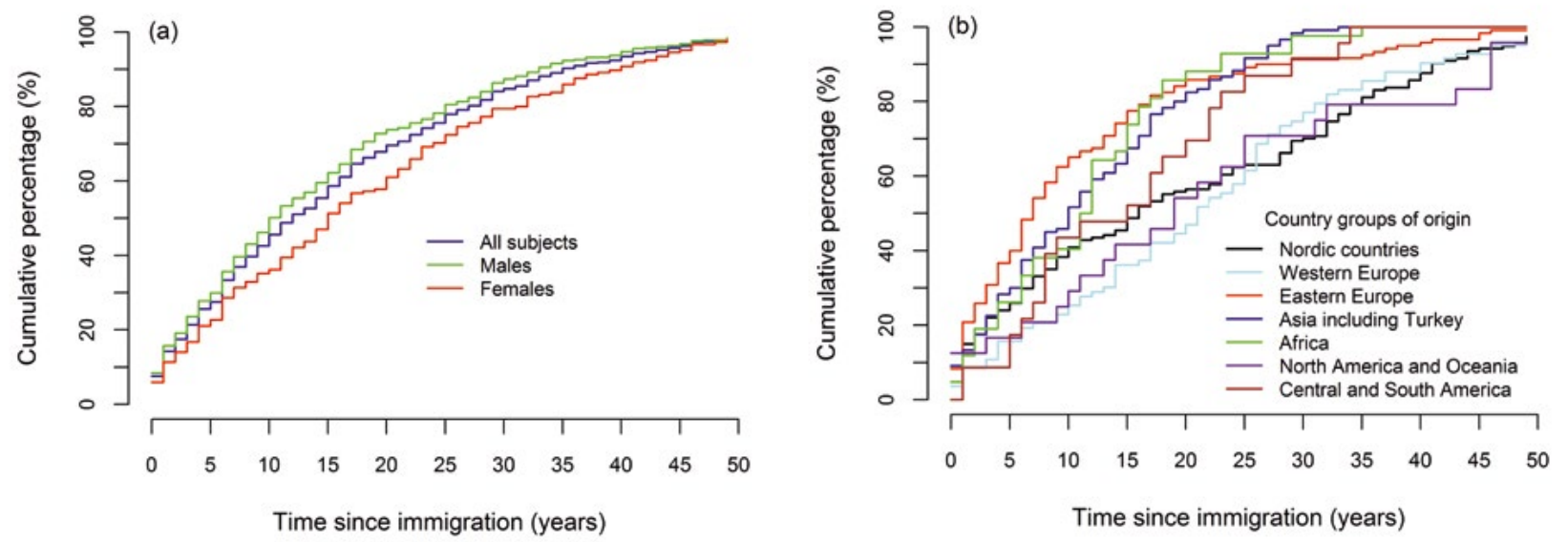

Source article: Puzo Q, Mehlum L, Qin P (2018). Rates and characteristics of suicide by immigration background in Norway. PLoS ONE 13(9):e0205035. doi:10.1371/journal.pone.0205035

More than $25 \%$ of all suicides in first-generation immigrants occurred during the first five years after immigrating to Norway. Overall differences in time to suicide since immigration were also observed by sex and country group of origin (Fig 3), in particular among those aged 35 years or less when moving to Norway. Male first-generation immigrants died by suicide significantly earlier after immigration than female firstgeneration immigrants $(P<0.01)$ with a median time to suicide since immigration of 10.85 years for males and 15.48 years for females. First-generation immigrants from Eastern Europe, Asia and Africa tended to die after fewer years of residence than those from Western Europe $(\mathrm{P}<0.01, \mathrm{P}<0.01$ and $\mathrm{P}<0.01$, respectively), reporting a median time to suicide since immigration of 7.26 years, 10.51 years, 11.79 years and 21.45 years respectively.

\section{Discussion}

Rates and risks of suicide and the impact of socio-economic factors

A core finding of our studies was that first-generation immigrants had a relatively lower rate and risk of suicide than native Norwegians, which is in accordance with previous studies from Sweden (Di Thiene et al., 2015; Hjern \& Allebeck, 2002). This may be partly explained by the 'healthy migrant effect', suggesting that first-generation immigrants tend to represent healthier segments of the population in the country of origin (Kennedy, McDonald, \& Biddle, 2006; Marmot, Adelstein, \& Bulusu, 1984), and by better employment opportunities and improved quality of life achieved by most immigrants in Norway (SSB, 2008, 2016a), compared to that in their country of origin. Moreover, our finding regarding the most reduced risk of suicide among first-generation immigrants from Asia and Africa suggests that immigrants from countries with low suicide rates, e.g. the Middle East and North Africa, tend to maintain the low suicide rate in their new country, as demonstrated in previous studies (Burvill, 1998; Hjern \& Allebeck, 2002; Ide et al., 2012; Leena Maria Johansson et al., 1997; Westman, Sundquist, Johansson, Johansson, \& Sundquist, 2006). In line with this notion, the non-significant difference in suicide risk between immigrants from Nordic countries and the natives may be explained by the fact that the major body of this group of immigrants were from Sweden and Denmark - countries with very similar suicide mortality rates to Norway (WHO, 2014).

We observed a very low suicide mortality among second-generation immigrants, but caution is needed when interpreting this finding since second-generation immigrants represent a relatively younger group of people in Norway, because immigrant population started to increase from the end of 196os. Moreover, 
the classification of second-generation immigrants was likely incomplete because of the lack of registered links to parents in the population registers before 1960 (Nystadnes, 2010).

Contrary to the first-generation immigrants' pattern, foreign-born persons with at least one Norwegian-born parent showed a higher rate and risk of suicide compared to native Norwegians. The analysed data sources did not enable us to gain more insights into this group but we speculated that a large proportion of this segment might represent intercountry adoptees, which have been shown to be a high-risk group for suicide (Hjern \& Allebeck, 2002; Hiern, Lindblad, \& Vinnerljung, 2002). Specifically, we found that individuals born in Asia and Central and South America with at least one Norwegian-born parent were at the highest risk of suicide compared to native Norwegians and that more than half of suicides of those born in Asia and Central and South America were from South Korea and Colombia respectively - two countries where most of intercountry adoptees in Norway originate from (SSB, 2015).

When analysing the impact of socio-economic factors on risk of suicide, we found that persons with an immigration background and the native Norwegians both shared most common risk factors for suicide such as being single, separated, divorced or widowed and having low educational attainment and low income, but the strength of such associations varied by immigration background. In particular, associations with socioeconomic risk factors (e.g. single marital status and low income) were generally weaker in first-generation immigrants than native Norwegians, but stronger in foreign-born persons with at least one Norwegian-born parent. Many first-generation immigrants come to Norway as single jobseekers (SSB, 2016b) and they represent a relatively younger age-group population (Henriksen, Østby, \& Ellingsen, 2011), thus being single is less likely perceived as a disadvantage. They also represented the least affected group regarding the suicide risk associated with low income. In contrast to first-generation immigrants, the finding that foreign-born persons with at least one Norwegian-born parent had a higher risk of suicide associated with not being married is hard to explain since the data sources did not allow us to gain more insights into this group. However, it seems reasonable to assume that for these individuals, a status of being married leads to a higher level of social support, social integration and settlement in life, all of which are normally factors protective against suicide (Kyung-Sook, SangSoo, Sangiin, \& Young-Jeon, 2018).

Another interesting finding was that first-generation immigrants living in the capital area (Oslo and Akershus counties) showed a lower risk of suicide than their counterparts settling elsewhere in Norway. This may be explained by the fact that first-generation immigrants are overrepresented in the capital area and thus the opportunities may increase for immigrants to obtain social support from individuals or groups coming from the same country of origin (Shaw et al., 2012). Indeed, over $40 \%$ of first-generation immigrants in Norway lived in this area in the period 1992-2012, whilst the correspondent proportion of national population living in the same area was only around $22 \%$ (SSB, 2017b, 2017c). The capital area may provide wider educational opportunities, a bigger job market and easier access to various immigrant communities, making first-generation immigrants feel less socially isolated. The influx of immigrants with Muslim religious affiliation in the Capital area (Titelman et al., 2013), might partly explain the observed reduced risk of suicide, since suicide is strongly forbidden in Islam.

\section{Method and seasonality of suicide, and time since immigration}

While hanging was the most common suicide method in all population groups regardless the immigration background, suicides by firearms represented a much smaller proportion of cases of first generationimmigrants (around $7 \%$ ) than cases of native Norwegians (around $21 \%$ ). We believed that this may reflect the access to the method of firearms which are likely more available in the homes of native Norwegians because of hunting traditions (private firearms ownership is around $30 \%$ of households (Alpers \& Marcus, 2018)) than in the households of first-generation immigrants.

In addition to the spring peak of suicides of first-generation immigrants, which has been previously found in the general Norwegian population and in other countries (Bramness, Walby, Morken, \& Røislien, 2015; Christodoulou, Efstathiou, Bouras, Korkoliakou, \& Lykouras, 2012; Hakko, Räsänen, \& Tiihonen, 1998; Postolache et al., 2010; Sumarokov, Brenn, Kudryavtsev, \& Nilssen, 2015), first-generation immigrants displayed another peak in the distribution of suicides in the month of November. The spring peak could be partly explained by the 'broken promise hypothesis', suggesting that suicidal thoughts are initiated in vulnerable persons when their expectations of better periods after cold winters are unmatched (Gabennesch, 1988; Hanigan, Butler, Kokic, \& Hutchinson, 2012), and by bioclimatic factors (such as increased sunshine, long photoperiod, tree pollen) which, inducing adverse changes in the hormones and dysfunctional 
emotion regulation, may increase the risk of mental ill-health and suicide (Petridou, Papadopoulos, Frangakis, Skalkidou, \& Trichopoulos, 2002). The fall peak of suicides of first-generation immigrants may be interestingly related to the meteorological changes that lead to dark and cold weather starting in November in Norway, with low temperatures and less sunlight. In Finland and Sweden the monthly peak of suicide in the fall occurred in October, which fully coincided with the biggest annual drop in the seasonal temperature (Holopainen, Helama, Björkenstam, \& Partonen, 2013). During such adverse weather, native Norwegians are more likely to spend time indoors with family and close friends, and therefore immigrants with poor social networks may feel even more isolated with less possibility of expanding their network.

The fact that male first-generation immigrants tended to die by suicide years earlier than female counterparts after moving to Norway might be related to the purpose of resettlement. As reported by Statistics Norway (SSB, 2016b), male first-generation immigrants move to this country mostly as jobseekers, whereas female first-generation immigrants often come to Norway for the purpose of family reunification and thus probably have better access to social support from their family already settled in the country (Norredam, Garcia-Lopez, Keiding, \& Krasnik, 2010). We also found that first-generation immigrants from Eastern Europe, Asia and Africa tended to die by suicide after fewer years of residence than did immigrants from Western Europe. This finding endorses a previous Norwegian study (Dalgard \& Thapa, 2007) reporting that immigrants from non-Western countries, areas more culturally distant from Norway, were less integrated and experienced higher levels of distress than those from countries culturally more similar to Norway, and that this discrepancy in the acculturation process was likely to be more evident for immigrants recently arrived.

\section{Limitations and Strengths}

Our findings should be interpreted in light of some limitations. Variables included in the three studies largely depended on the availability of the data in the source databases. For instance, we were unable to consider reason for immigration, information on mental disorders, and history of suicide attempts - variables that were not included in our data sources but could provide further insights in suicide characteristics and a more "prevention" perspective to the findings. Moreover, socio-economic measures, such as marital status, education attainment, annual gross income and place of residence, were only available from the year 1992, so when analysing the period 1969-2012 we provided only crude estimates of risk for suicide by immigration background. Additionally, our studies only focused on immigrants who had received legal residence permission in Norway, without taking into account refugees

temporarily living in the country, asylum seekers or illegal immigrants.

A key strength of our studies was the use of national longitudinal registers where data were collected systematically and uniformly and covers all residents of the country over a delineated time period. The data collected without the purpose of any specific research projects reduced the risk of differential misclassification bias. The use of existing register data also eliminated types of bias such as the recall bias often associated with obtaining data via interviews. Moreover, the large number of suicides included in these studies yielded good statistical power for estimating differences between natives and various immigrant populations. In addition, the use of a nested case-control design, in the context of register data to study a rare event like suicide, avoided possible computational burden associated with a large sample and time-dependent explanatory variables.

\section{Conclusions and Implications}

Our studies (Puzo et al., 2017, 2018a, 2018b) have provided rich insights into suicide by immigration background, which are of clear importance from both public health and policy perspectives. The findings underscore the importance of not treating immigrants as a homogeneous group, as the rates, risks, and characteristics of suicide vary according

The findings underscore the imporimmigrants as a homogeneous group, as the rates, risks, and characteristics of suicide vary according to their immigration background. tance of not treating

to their immigration background. People involved in planning public health policies and prevention measures should be aware of the differences in immigrants' culture of origin and differences in characteristics of suicides by specific immigration background, in order to more effectively tailor these measures to at-risk immigrant populations. Measures to improve

immigrants' social integration and social support, and to overcome barriers and difficulties, such as language difficulties, lack of knowledge about available mental health services or even fear of stigma associated with having mental health problems, should be implemented and have a beneficiary effect on mental well-being in immigrant population. In particular, self-management e-resources can play a potentially important role in helping to ensure that people get the care and support they need while offering them the alternative to maintain anonymity (Karasouli \& Adams, 2014).

Although first-generation immigrants were shown to represent a group of population with a low risk for 
suicide, possibly due to factors involved in their own selection, their own choice and strength, our results indicate the need of focus on people with a mixed Norwegian and immigrant background. Possible conflicts between two parents of very different cultures and the stress of becoming part of the majority population while seeking to remain loyal to their original ethnic culture may result in a loss of integration, intergenerational conflicts, and thus suicidal behaviours. Nevertheless, future studies are needed to disentangle what specific factors and conditions are involved in the increased risk for suicidal behaviour in people with a mixed background. At the same time, large-scale investigations from various social settings are warranted to pinpoint high-risk segments of the immigrant population and to take into account desirable variables such as reason for immigration, psychiatric history, and exposure to stressful life events, for further insights to guide prevention measures.

Levert: 5.11.18 - Revidert: 23.02.2019 17:50 - Godkjent: 10.05.19

\section{REFERENCES}

Alpers, P., \& Marcus, W. (2018). Norway - Gun Facts, Figures and the Law. Retrieved from http://www.gunpolicy.org/firearms/region/norway

Berkman, L. F., Glass, T., Brissette, I., \& Seeman, T. E. (2000). From social integration to health: Durkheim in the new millennium. Soc Sci Med, 51(6), 843-857.

Bhugra, D. (2004). Migration and mental health. Acta psychiatrica scandinavica, 109(4), 243-258.

Bhugra, D., \& Becker, M. A. (2005). Migration, cultural bereavement and cultural identity. World psychiatry, 4(1), 18.

Bramness, I. G., Walby, F. A., Morken, G., \& Røislien, I. (2015). Analyzing seasonal variations in suicide with Fourier Poisson time-series regression: a registry-based study from Norway, 1969-2007. American journal of epidemiology, 182(3), 244-254.

Burvill, P. (1998). Migrant suicide rates in Australia and in country of birth. Psychol Med, 28(01), 201-208.

Christodoulou, C., Efstathiou, V., Bouras, G., Korkoliakou, P., \& Lykouras, L. (2012). Seasonal variation of suicide. A brief review. Encephalos, 49, 73-79.

Clayton, D., Hills, M., \& Pickles, A. (1993). Statistical models in epidemiology (Vol. 161). Oxford: Oxford University Press.

Collett, D. (1991). Modelling binary data. London: Chapman \& Hall/CRC.

Dalgard, O. S., \& Thapa, S. B. (2007). Immigration, social integration and mental health in Norway, with focus on gender differences. Clinical Practice and Epidemiology in Mental Health, 3(1), 24.

Di Thiene, D., Alexanderson, K., Tinghög, P., La Torre, G., \& MittendorferRutz, E. (2015). Suicide among first-generation and second-generation immigrants in Sweden: association with labour market marginalisation and morbidity. I Epidemiol Community Health, 69(5), 467-473.

Gabennesch, H. (1988). When promises fail: a theory of temporal fluctuations in suicide. Social Forces, 67(1), 129-145.

Hakko, H., Räsänen, P., \& Tiihonen, I. (1998). Seasonal variation in suicide occurrence in Finland. Acta psychiatrica scandinavica, 98(2), 92-97.

Hanigan, I. C., Butler, C. D., Kokic, P. N., \& Hutchinson, M. F. (2012). Suicide and drought in new South Wales, Australia, 1970-2007. Proceedings of the National Academy of Sciences, 109(35), 13950-13955.
Henrik Mäkinen, I., \& Wasserman, D. (2003). Suicide mortality among immigrant Finnish Swedes. Arch Suicide Res, 7(2), 93-106.

Henriksen, K., Østby, L., \& Ellingsen, D. (2011). Immigration and immigrants 2010. Retrieved from https://www.ssb.no/en/befolkning/artikler-og-publikasioner/immigration-and-immigrants-2010

Hiern, A., \& Allebeck, P. (2002). Suicide in first-and second-generation immigrants in Sweden A comparative study. Soc Psychiatry Psychiatr Epidemiol, 37(9), 423-429.

Hiern, A., Lindblad, F., \& Vinnerliung, B. (2002). Suicide, psychiatric illness, and social maladjustment in intercountry adoptees in Sweden: a cohort study. Lancet, 360(9331), 443-448.

Holopainen, I., Helama, S., Biörkenstam, C., \& Partonen, T. (2013). Variation and seasonal patterns of suicide mortality in Finland and Sweden since the 1750s. Environmental health and preventive medicine, 18(6), 494.

Ide, N., Kolves, K., Cassaniti, M., \& De Leo, D. (2012). Suicide of first-generation immigrants in Australia, 1974-2006. Soc Psychiatry Psychiatr Epidemiol, 47(12), 1917-1927.

Johansson, L. M., Sundquist, I., Johansson, S. E., Bergman, B., Qvist, I., \& Träskman-Bendz, L. (1997). Suicide among foreign-born minorities and Native Swedes: an epidemiological follow-up study of a defined population. Soc Sci Med, 44(2), 181-187.

Johansson, L. M., Sundquist, I., Johansson, S. E., Qvist, I., \& Bergman, B. (1997). The influence of ethnicity and social and demographic factors on Swedish suicide rates. A four year follow-up study. Soc Psychiatry Psychiatr Epidemiol, 32(3), 165-170.

Karasouli, E., \& Adams, A. (2014). Assessing the evidence for e-resources for mental health self-management: a systematic literature review. IMIR mental health, 1(1).

Kennedy, S., McDonald, I. T., \& Biddle, N. (2006). The healthy immigrant effect and immigrant selection: evidence from four countries. In: Citeseer.

Kliewer, E. (1991). Immigrant suicide in Australia, Canada, England and Wales, and the United States. I Aust Popul Assoc, 8(2), 111-128.

Kliewer, E. V., \& Ward, R. (1988). Convergence of immigrant suicide rates to those in the destination country. Am I Epidemiol, 127(3), 640-653.

Kposowa, A. I., McElvain, I. P., \& Breault, K. D. (2008). Immigration and suicide: The role of marital status, duration of residence, and social integration. Arch Suicide Res, 12(1), 82-92.

Kyung-Sook, W., SangSoo, S., Sangiin, S., \& Young-Jeon, S. (2018). Marital status integration and suicide: A meta-analysis and meta-regression. Soc Sci Med, 197, 116-126. doi:10.1016/i.socscimed.2017.11.053

Law, C.-k., Kõlves, K., \& De Leo, D. (2014). Suicide mortality in second-generation migrants, Australia, 2001-2008. Soc Psychiatry Psychiatr Epidemiol, 49(4), 601-608.

Marmot, M. G., Adelstein, A. M., \& Bulusu, L. (1984). Lessons from the study of immigrant mortality. Lancet, 323(8392), 1455-1457.

Mirsky, I., Kohn, R., Dolberg, P., \& Levav, I. (2011). Suicidal behavior among immigrants. Soc Psychiatry Psychiatr Epidemiol, 46(11), 1133-1141.

Mirsky, I., Kohn, R., Levav, I., Grinshpoon, A., \& Ponizovsky, A. M. (2008). Psychological distress and common mental disorders among immigrants. results from the Israeli-based component of the World Mental Health Survey. I Clin Psychiatry, 69(11), 1715-1720.

Norredam, M., Garcia-Lopez, A., Keiding, N., \& Krasnik, A. (2010). Risk of mental disorders in family reunification migrants and native Danes: a register-based historically prospective cohort study. International journal of public health, 55(5), 413.

Nystadnes, T. (2010). Identifikatorer for personer. Retrieved from Petridou, E., Papadopoulos, F. C., Frangakis, C. E., Skalkidou, A., \& Trichopoulos, D. (2002). A role of sunshine in the triggering of suicide. Epidemiology, 13(1), 106-109.

Postolache, T. T., Mortensen, P. B., Tonelli, L. H., Jiao, X., Frangakis, C., Soriano, I. I., \& Qin, P. (2010). Seasonal spring peaks of suicide in victims 
with and without prior history of hospitalization for mood disorders. Journal of affective disorders, 121(1), 88-93.

Puzo, Q., Mehlum, L., \& Qin, P. (2017). Suicide among immigrant population in Norway: a national register-based study. Acta Psychiatr Scand, 135(6), 584-592. doi:10.1111/acps.12732

Puzo, Q., Mehlum, L., \& Qin, P. (2018a). Rates and characteristics of suicide by immigration background in Norway. PloS ONE, 13(9). doi:10.1371/journal. pone.0205035

Puzo, Q., Mehlum, L., \& Qin, P. (2018b). Socio-economic status and risk for suicide by immigration background in Norway: A register-based national study. Journal of Psychiatric Research, 100, 99-106. doi:10.1016/i.jpsychires.2018.02.019

Ratkowska, K. A., \& Leo, D. D. (2013). Suicide in Immigrants: An Overview. Open I Med Psychol, Vol.o2No.03, 10.

RCoreTeam. (2017). R: A language and environment for statistical computing. Retrieved from https://www.R-project.org/

Shaw, R. I., Atkin, K., Bécares, L., Albor, C. B., Stafford, M., Kiernan, K. E., . . . Pickett, K. E. I. T. B. I. o. P. (2012). Impact of ethnic density on adult mental disorders: narrative review. 201(1), 11-19.

SSB. (2003). Norwegian Standard Classification of Education. Revised 2000 Retrieved from https://www.ssb.no/a/english/publikasioner/pdf/nos_c751 en/nos_c751_en.pdf

SSB. (2008). Living conditions among immigrants. Retrieved from https://www.ssb.no/en/sosiale-forhold-og-kriminalitet/statistikker/innvlev/ hvert-10-aar

SSB. (2015). Adoptions. Retrieved from https://www.ssb.no/en/befolkning/ statistikker/adopsion/aar

SSB. (2016a). Employment among immigrants. Retrieved from https://www.ssb.no/en/innvregsys

SSB. (2016b). Immigrants by reason for immigration. Retrieved from https://www.ssb.no/en/befolkning/statistikker/innvgrunn

SSB. (2017a). Immigrants and Norwegian-born to immigrant parents. Retrieved from http://www.ssb.no/en/befolkning/statistikker/innvbef

SSB. (2017b). Table 03031: Population, by sex, age and marital status. 1 Ianuary $(C)$. Retrieved from https://www.ssb.no/statistikkbanken/selecttable/hovedtabellHiem.asp?KortNavnWeb=folkemengde\&CMSSubjectArea=be folkning \&PLanguage $=1 \&$ checked $=$ true

SSB. (2017C). Table 05182: Persons, by immigration category and sex (C) Retrieved from https://www.ssb.no/statistikkbanken/selecttable/hovedtabellHiem.asp?KortNavnWeb=innvbef\&CMSSubiectArea=befolkning\& PLanguage $=1 \&$ checked $=$ true

SSB. (2017d). Tax statistics for personal tax payers. Retrieved from http://www.ssb.no/en/selvangivelse
Sumarokov, Y. A., Brenn, T., Kudryavtsev, A. V., \& Nilssen, O. (2015). Variations in suicide method and in suicide occurrence by season and day of the week in Russia and the Nenets Autonomous Okrug, Northwestern Russia: a retrospective population-based mortality study. BMC psychiatry, 15(1), 224 .

Titelman, D., Oskarsson, H., Wahlbeck, K., Nordentoft, M., Mehlum, L., Jiang, G.-X., ... Wasserman, D. (2013). Suicide mortality trends in the Nordic countries 1980-2009. Nord I Psychiatry, 67(6), 414-423.

Westman, I., Sundquist, I., Johansson, L. M., Johansson, S.-E., \& Sundquist, K. (2006). Country of birth and suicide: a follow-up study of a national cohort in Sweden. Archives of Suicide Research, 10(3), 239-248.

WHO. (2014). Suicide rates (per 100 ooo population). Retrieved from http://www.who.int/gho/mental_health/suicide_rates/en/

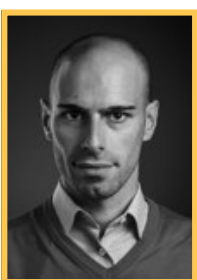

QUIRINO PUZO, PH.D. is a data analyst at BI Norwegian Business School - Oslo. He received his $\mathrm{Ph} . \mathrm{D}$ in epidemiology from the National Centre for Suicide Research and Prevention (NSSF) - University of Oslo with focus on suicide among immigrants.

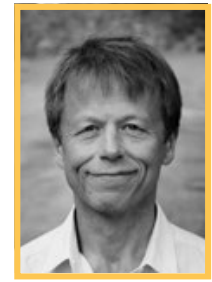

LARS MEHLUM, MD, PhD, is the founding director of the National Centre for Suicide Research and Prevention, and professor of psychiatry and suicidology at the Institute of Clinical Medicine, University of Oslo.

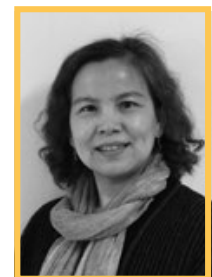

PING QIN, MD, PhD, is professor at National Center for Suicide Research and Prevention, University of Oslo, and head of research group for register-based study on suicide and deliberate self-harm. 